\title{
Medicolegal Evaluation of Elderly Trauma Patients
}

\section{Geriatrik Adli Olgularda Travmanın Yeri}

\author{
Dilek Durak ${ }^{1,2}$, Mustafa Numan Ural ${ }^{1}$, Recep Fedakar ${ }^{1,2}$, Murat Serdar Gürses $^{1}$, Okan Akan ${ }^{2}$, Nursel Türkmen \\ Inanir ${ }^{1,2}$, Selçuk Çetin ${ }^{3}$
}

${ }^{1}$ Uludag University School of Medicine, Department of Forensic Medicine, Bursa

${ }^{2}$ Council of Forensic Medicine of Bursa Department, Bursa

${ }^{3}$ Gaziosmanpasa University School of Medicine, Department of Forensic Medicine, Tokat

\section{Abstract}

Objective: The human body loses flexibility and durability from the pathophysiological changes of aging; therefore, trauma and the risk of injury increase in geriatric individuals. Elderly patients who have been admitted to health centers with trauma and injury require a serious treatment approach.

Materials and Methods: A total of 15851 victims who were admitted to Bursa Branch of the Council of Forensic Medicine of the Ministry of Justice between 01/01/2011 and 31/12/2011 were retrospectively evaluated, and 207 of them, who were trauma patients aged 65 years and over, were included in this study. All cases were evaluated according to the cause of the injury, localization of the trauma, bone fractures and type of medical treatment.

Results: Two hundred nineteen of the total 15851 forensic patients were 65 years and older. Of these 219 cases, 207 (94.5\%) had been exposed to trauma. Of these 207 cases, 138 (66.7\%) were male, and 69 (33.3\%) were female. The most common types of trauma were physical assault $(n=136)$ and motor vehicle accidents $(n=56)$, which occurred at rates of $65.7 \%$ and $27.1 \%$, respectively. For the trauma victims, head injury was the most commonly affected body region. Ninety-seven patients were treated conservatively (46.9\%), and 43 patients were treated surgically (20.8\%). Traumatic bone injury (31\%) was detected in 64 patients.

Conclusion: The results of our study indicate that most of the geriatric victims were admitted to the medical centers with traumatic causes. Thus, it is necessary to increase our social sensitivity to trauma and the ways in can be prevented in the geriatric age group.

Key words: Trauma, Geriatric, Forensic case, Injury.

\section{Özet}

Amaç: İnsan vücudunun esneklik ve dayanıklılığı yaşlanmanın patofizyolojik değişiklikleri ile kaybolmaktadır. Bu nedenle, geriatrik bireylerde travma riski ve yaralanmada artış olması travma nedeniyle sağlık merkezlerine başvuran yaşlı hastalar için ciddi bir tedavi yaklaşımı gerektirir.

Gereç ve Yöntem: Çalışmamızda 01/01/2011-31/12/2011 tarihleri arasında Adli Tıp Kurumu Bursa Adli Tıp Şube Müdürlügü’’ne başvurusu bulunan 15851 adli vaka arasından 207 adet 65 yaș ve üstui travma olgusu retrospektif olarak incelendi. Tüm veriler adli raporlardaki tıbbi kayıtlardan elde edildi. Olgular yaş, cinsiyet, yaralanma nedeni, travma türü, kemik kırıklarının lokalizasyonu ve tedavi türü şeklinde değerlendirildi.

Bulgular: 15.851 adli olgunun 219'u 65 yaş ve üzeri idi. Bu olgulardan 207'si (\%94.5) travmaya maruz kalmıștı. 207 olgunun, 138’i (\%66.7) erkek, 69'u (\%33.3) kadındı. Travmanın en yaygın türleri sırasıyla fiziksel saldırı \%65.7 ( $\mathrm{n}=136)$ ve motorlu tașit kazaları \%27,1 $(n=56)$ olarak tespit edildi. Baş en sık maruz kalınan vücut bölgesi olarak izlendi. Olguların 97'si (\%46.9) konservatif olarak, 43’ü (\%20.8) cerrahi olarak tedavi edilmiști. Travmatik kemik kırıkları 64 (\%31) olguda tespit edildi.

Sonuç: Çalışmamız, geriatrik adli olguların çoğunluğunun travmatik nedenler ile tıbbi merkezlere başvurduğunu göstermektedir. $\mathrm{Bu}$ sonuçlar, geriatrik yaş grubunda önlenebilir travma nedenleri konusunda sosyal duyarlılı̆̆ın artmasını sağlayacaktır.

Anahtar Kelimeler: Travma, Geriatri, Adli olgu, Yaralanma.

\section{Introduction}

The World Health Organization (WHO) defines geriatric age as 65 years and older (1). The elderly population accounts for $7.7 \%$ of the overall population in 2013 , which is estimated to increase to $10.2 \%$ in 2023 in Turkey (2).

The health of the elderly is seriously affected in traumatic situations. When elderly individuals are exposed to trauma, their risk of injury is higher than that of young individuals who

Corresponding Author: Murat Serdar Gürses,

Uludag University School of Medicine, Departmant of Forensic Medicine,

Bursa Phone: +902242220347 Fax:+0902242255170

E-mail: godbavo@hotmail.com experience a similar severity of trauma (3). Trauma is the fifth most common cause of death in the elderly population, and $28 \%$ of geriatric trauma patients die from trauma (4-6). In addition, the physiological and metabolic changes of aging reduce an individual's ability to cope with traumatic stress. For this reason, longer treatment durations and higher complication rates are observed in the elderly (7-9). Criminal issues, such as abuse in the geriatric population, are also important risk factors in terms of the mortality and morbidity. Therefore, elderly patients who are referred to medical centers should be examined using a multidisciplinary approach. The aim of this study was to determine the demographic and etiologic characteristics of elderly forensic patients. 


\section{Materials and Methods}

In this study, we retrospectively evaluated 207 geriatric trauma patients who were admitted to the Bursa Branch of the Council of Forensic Medicine of the Ministry of Justice in 2011. The information obtained from the legal reports was used. The patients' age, gender, trauma type, location of trauma, treatment modalities used in the healthcare services and presence of bone fractures were evaluated. Reported fractures were confirmed with radiologic investigations. Categorical data were compared between the genders and age groups using Fisher's exact test or chi-square tests, as needed.

\section{Results}

A total of 15851 victims were admitted to Bursa Branch of the Council of Forensic Medicine of the Ministry of Justice between 01/01/2011 and 31/12/2011. Two hundred nineteen of the patients were in the geriatric age group ( $\geq 65$ years). Two hundred seven of these patients suffered from traumatic causes and were included in our study. Twenty-one patients (9.5\%) were victims of physical abuse in the geriatric age group. The excluded 12 patients were referred for evaluation due to intoxication, social cure, respite and legal capacity.

Of 207 cases, 138 (66.7\%) were male, and 69 (33.3\%) were female. In this study, the age range of the patients was 65-91 years. One hundred fifty-seven were between 65 and 74 years of age, and the remaining 50 were over 74 years of age. The complaints were assault in $136(65.7 \%)$ patients, traffic accidents in 56 (27.1\%) patients, stabbing in 9 (4.4\%) patients, firearm injuries in 3 (1.4\%) patients and falling down in $3(1.4 \%)$ patients. The types of trauma according to age groups and gender are listed in Tables 1 and 2. Assault was significantly more common in females. Seventy-three (35.2\%) patients had isolated head injury, 64 (31\%) patients had isolated extremity injury, 10 (4.8\%) patients had isolated thoracoabdominal injury and 60 (29\%) patients had injuries localized on multiple regions of the body. Traumatic bone fractures were detected in 64 (31\%) of the patients. Forty-three of the 64 patients with detected bone fractures were males, and 21 were females. The cranial and facial regions were the most frequent fracture sites, which was followed by the extremities and thoracic bone

Table 1. Trauma types according to gender.

\begin{tabular}{|c|c|c|c|}
\hline Trauma type & Female & Male & $\mathbf{p}$ \\
\hline Assault & $\mathbf{7 5 . 4 \%}$ & $\mathbf{6 0 . 9} \%$ & $\mathbf{0 . 0 3 8}$ \\
\hline $\begin{array}{c}\text { Motor vehicle } \\
\text { accident }\end{array}$ & $21.7 \%$ & $29.7 \%$ & $>0.05$ \\
\hline Stabbing & $1.4 \%$ & $5.8 \%$ & $>0.05$ \\
\hline Firearm injury & 0 & $2.2 \%$ & $>0.05$ \\
\hline Falls & $1.4 \%$ & $1.4 \%$ & $>0.05$ \\
\hline
\end{tabular}

Table 2. Trauma types according to age groups.

\begin{tabular}{|c|c|c|c|}
\hline Trauma type & $\mathbf{6 5 . 7 4}$ years & $>\mathbf{7 5}$ years & $\mathbf{p}$ \\
\hline Assault & $67.5 \%$ & $60 \%$ & $>0.05$ \\
\hline $\begin{array}{c}\text { Motor vehicle } \\
\text { accident }\end{array}$ & $26.8 \%$ & $28 \%$ & $>0.05$ \\
\hline Stabbing & $5.1 \%$ & $2 \%$ & $>0.05$ \\
\hline Firearm injury & $0.6 \%$ & $4 \%$ & $>0.05$ \\
\hline Falls & 0 & $\mathbf{6 \%}$ & $>\mathbf{0 . 0 5}$ \\
\hline
\end{tabular}

structures. Individuals with bone fracture included 35 patients who were in traffic accidents, 26 assault patients, 2 patients who had fallen and one firearm injury. Ninety-seven (46.9\%) patients were treated conservatively, and 43 (20.8\%) patients were treated surgically.

\section{Discussion}

A criminal event is defined as an intentional event or a suicidal or homicidal attempt that incurs a disruption of physical and psychological integrity or death (10). The most common cause of admission to medical centers in elderly trauma patients is an accident. However, abuse victims are not rare. Such elder abuse may occur in the form of economic, physical, emotional, sexual, verbal or mental abuse. At the same time, family members or caregivers may neglect older individuals. For these reasons, abuse and neglect are issues that merit draw particular attention. When the elderly patients are admitted to medical or judicial centers with accidental situations, a careful examination should be performed $(11,12)$. According to studies conducted in Canada, estimates of the prevalence of elder abuse have ranged from $4 \%$ to $10 \%$ (13). Prevalence studies in the United States estimate that more than one million elderly persons are victims of abuse annually, and up to $25 \%$ have been physically abused (14). In our study, we determined twenty-one (9.5\%) physical abuses in the geriatric age group ( $\mathrm{n}=219)$, and were detected (15.4\%) among physical assault victims $(\mathrm{n}=136)$.

Though motor-vehicle accidents and falls were the most frequent causes in the other studies conducted on elderly forensic cases $(15,16)$, the most common types of traumas in our study of elderly forensic patients were physical assaults and motor-vehicle accidents. Because the risk of falls increases with aging, a lower proportion of individuals over 74 years of age may have decreased the proportion of falls in our study. Furthermore, there was a significant increase in the fall rate with aging.

In one study, the head (40.3\%), extremities (35.1\%) and chest (3.9\%) were the most commonly injured body parts (15). Another study suggested that the head (\%35.3) and extremities (38.7\%) were the most commonly injured parts of the body (17). 
Our data are in accordance with these studies.

Bilgin et al. detected bone fractures in 33 (\%40.7) patients in their study. The fractures were localized on the extremities (\%53.8), head (\%10.3), and ribs (\%10.3) (4). We detected bone fractures in 64 (\%31) of our patients. The proportions of fracture localizations were similar for our study.

Despite the female dominance in the general elderly population, there was a male dominance (2:1) in our study. This finding suggests that the risk of involvement in an elder criminal case is higher in males. In contrast to our study, a study performed by Bilgin et al indicated that the ratio of males to females was nearly $1: 1$ ( $n=40$ vs. 41 , respectively) (15). However, in another study published by Kandiş et al, 155 of the 224 cases were males, and 69 were females (16).

\section{Conclusion}

The most common sites of injury were the head and extremities. Assaults and motor vehicle injuries were the main causes of injury. To meet the needs of an aging society, more action is needed in the future to prevent assaults, motor vehicle accidents and fall injuries and to minimize the incidence of injury, abuse, and neglect among the elderly.

\section{References}

1. http://www.who.int/healthinfo/survey/ageingdefnolder/en (Dec 18, 2015)

2. http://www.tuik.gov.tr/PreHaberBultenleri.do?id=16057 (Dec 18,2015)

3. Runciman P, Currie CT, Nicol M et al. Discharge of elderly people from an accident and emergency department: evaluation of health visitor follow-up. J Adv Nurs 1996; 24:711-8.
4. Schwab CW, Kauder DR. Trauma in the geriatric patient. Arch Surg. 1992; 127(6):701-6.

5. Ma OJ, DeBehnke DJ. Geriatric trauma. In: Tintinalli J, Kelen GD, Stapcznski JS, editors. Emergency Medicine, A comprehensive Study Guide, 5th ed. New York: McGraw-Hill; 1999.p.1623-7.

6. Rubenstein LA, Robbins AS, Josephson KR. The value of assessing falls in an elderly population - A randomized clinical trial. Ann İntern Med 1990; 15:113-308.

7. Baum SA, Rubenstein LZ. Old people in the emergency room: agerelated differences in emergency department use and care. J A Geriatr Soc 1987; 35(5):398-404.

8. İkizceli İ, Sözüer EM, Bedirli A, Yıldırım C, Günay N, Yürümez Y. Multitravmalı hastaların prognozunu belirlemede yaş faktörü. Turkish Journal of Trauma and Emergency Surgery 1999; 5(1):402.9. Ünsal $A$, Çevik AA, Metintaşı S, Arslantaşı D, İnan OÇ. Yaşlı hastaların acil servise başvuruları. Geriatri 2003; 6(3):83-88.

10. Kök AN, Özturk S. Tunalı İ. Yatarak Tedavi Gören 959 Adli Vakanın Retrospektif Değerlendirilmesi. J For Med. 1992; 8(1-2-34): 93-98.

11. Polat O, İnanıcı MA, Aksoy ME. Adli Tıp Ders Kitabı. Nobel Tip Kitapevi 1997; 140-141, 175-176.

12. Elder Abuse and Neglect, Recognizing Elder Abuse. http://www.oactrees.org/elder.

13. Walsh CA, Yon Y. Developing an empirical profile for elder abuse research in Canada. J Elder Abuse Negl. 2012;24(2):104-19.

14. Switzer JA, Michienzi AE. Elder abuse: an update on prevalence, identification, and reporting for the orthopaedic surgeon. J Am Acad Orthop Surg. 2012; 20(12):788-94.

15. Bilgin NG, Mert E. The Characteristics of Geriatric Forensic Cases. Turkish Journal of Geriatrics 2005; 8(1): 13-16.

16. Kandiş H, Karakuş A, Katırcı Y, Karapolat S, Kara İH. Geriatric population and forensic traumas. Turkish Journal of Geriatrics 2011; 14(3) 193-198.

17. Güneytepe Üİ, Aydin ŞA, Gökgöz Ş, Özgüç H, Ocakoğlu G, Aktaş $\mathrm{H}$. Factors affecting mortality and scoring systems in elderly trauma patients. Uludağ Medical Journal 2008.34 (1) 15-19. 